\title{
Metal Concentration in Vegetables Grown in the Hydrothermally Affected Area in Ethiopia
}

\author{
Tamiru Alemayehu Abiye (Corresponding author) \\ School of Geosciences, University of the Witwatersrand \\ Private Bag X3, P.O.Box Wits 2050, Johannesburg, South Africa \\ E-mail: tamiru.abiye@wits.ac.za \\ Hameed Sulaiman \\ College of Science, Sultan Qaboos University \\ P.O.Box 36, PC 123, Al-Khodh, Muscat, Sultanate of Oman \\ E-mail: hameed@squ.edu.om
}

Amare Hailu

Rift valley branch office Co-ordinater, Horn of Africa Regional Environment Center/Network

P.O.Box 80773, Addis Ababa, Ethiopia

E-mail: amarechu@yahoo.com; amareh@hoarec.org

Received: June 22, 2010 Accepted: July 9, 2010 doi:10.5539/jgg.v3n1p86

\begin{abstract}
Being at the top of the food chain, man is the main receiver of unwanted metals through vegetable consumption. The situation is exacerbated in developing countries due to the lack of regulations where people consume vegetables grown using polluted soil and water. Most of the research works conducted in Addis Ababa revealed that the concentration of metals in vegetables reached toxic level and it was attributed, exclusively, to the industrial sources. To investigate the impact of natural environmental changes, in the current work, vegetable, water and soil samples were collected from the northern part of the city of Addis Ababa where there is no industrial activities and Ziway area in the Main Ethiopian Rift. Ziway area was selected as a control point due to its location, which is away from the industrial activities. Populated area and rural area were compared to investigate for the concentrations of metals such as $\mathrm{Cd}, \mathrm{Cr}, \mathrm{Pb}$ and $\mathrm{Zn}$, in soils, vegetables and irrigation water in order to understand the magnitude of metals in the edible part of the vegetables. The results indicate that vegetables that are grown in industrially free area of northern part of Addis Ababa, which are destined to the domestic consumption, contain high level of metals that are generated from geogenic sources. Until recent days, industrial pollution was attributed to be the main source of metals in the city's irrigation water and irrigated vegetables, however, natural sources are widespread in the city. It is presumed that long time consumption of vegetables loaded with metals could pose health risk.
\end{abstract}

Keywords: Addis Ababa, Geogenic source, Hydrothermal activity, Metal contamination, Vegetables

\section{Introduction}

Heavy metals are elements that have relatively high density and are toxic or poisonous even at low concentrations, but excessive levels can be detrimental to the organism (Hem, 1992).

The ecological crisis of environmental pollution has been blamed on different factors and one of the major factors is the pollution due to metals in the environment. Natural and anthropogenic sources of soil contamination are widespread and variable. Industrial and mining activities are the main antropogenic activities that generate metals into the environment (Riewerts and Farango, 1996; Ustayak and Petrikova, 1996; Lacatusu et al., 1996; Landberg and Greger, 1996; Verner and Ramsy, 1996; Lee et al., 2001; Jung 2001; Li et al., 2001; Breward, 2003; Sindenko et al., 2005; Getaneh and Alemayehu, 2006). Different studies indicate that natural 
sources of metals are related to geological and weathering processes, which releases them into soils (Hem, 1992; Alemayehu, 2006). Klein (1972) has documented heavy metal contamination in soils, collected within the industrial district in United States of America and compared it with non-industrial or nearly agricultural areas and has reported that metals such as Silver $(\mathrm{Ag})$, Cadmium $(\mathrm{Cd})$, Cobalt $(\mathrm{Co})$, Chromium $(\mathrm{Cr})$, Copper $(\mathrm{Cu})$, Iron $(\mathrm{Fe})$, Nickel $(\mathrm{Ni})$, Lead $(\mathrm{Pb})$, Zink $(\mathrm{Zn})$ and Mercury $(\mathrm{Hg})$ as contaminants in the non-industrial areas. In localized mineral zones or around volcanoes an elevated level of the metals such as Arsenic (As), $\mathrm{Pb}, \mathrm{Cd}, \mathrm{Cu}$ and $\mathrm{Zn}$ can also be found (Salomons and Forstner, 1988).

The prevalence of contamination from both natural and anthropogenic sources has increased concern about the health effects of chronic low-level exposures. Plants being the important member of the food-chain may create a risk for man and animals through contamination of food supplies. Certain plants can accumulate metals in their tissues and uptake generally increases in plants that are grown in areas with increased soil concentrations (Khan and Frankland, 1983; Ustayak and Petrikova, 1996; Lacatusu et al., 1996). Metals such as $\mathrm{Cd}$ and $\mathrm{Pb}$ have long been known as a major contamination problem, not only for working conditions but also for the environment (Freiberg et al., 1997). From the other side, although $\mathrm{Zn}$ and $\mathrm{Cu}$ are essential trace elements which may also serve as plant nutrients, their undue presence in the environment can also be hazardous to man (WHO, 1984).

Of the nonessential metals, $\mathrm{Pb}$ and $\mathrm{Cd}$ are recognized as hazardous and have caused major health problems as a result of environmental pollution (Berglund et al., 1984). $\mathrm{Pb}$ and $\mathrm{Cd}$ have no essential biological functions and are highly toxic to plants, animals and humans (Pendias and Pendias, 1992), Cd being relatively more toxic, in lower concentrations, than $\mathrm{Pb}$ to plants (Alloway, 1994). Being at the top of the food chain, man is the final receiver of all these metals stored in the vegetables.

The problems of metal contamination in the vegetable farms in the city of Addis Ababa and their accumulation on the vegetables have been recorded by Itanna, (2002); Itanna and Olsson, (2004). However, these works have detailed report on metal accumulation in vegetables associated with industrial contaminations in the city of Addis Ababa. The metal genesis reported by Alemayehu (2006), instead, indicated that a geogenic source from deeper crust and/or mantle in the form of hydrothermal activity has affected the chemical composition of volcanic rocks and was responsible for the metal concentrations in the urban environment of Addis Ababa, where anthropogenic input is minor. Alemayehu (2001) has also reported high concentration of metals such as $\mathrm{Cr}, \mathrm{Ni}$ etc. in the streams and springs of the northern part of Addis Ababa.

The main motivation of this work is to reveal the role of geological source of metal contamination in vegetables that are grown in metals rich soils in and around the city of Addis Ababa. It, mainly, focuses on vegetables such as lettuce, Swiss chard, Ethiopian kale, and carrot in addition to soils and irrigation water. The vegetable samples were collected from the northern part of the city where there is no industrial activity. Comparison was performed with vegetables grown in the rural part of the Ziway area in the Main Ethiopian Rift (Figure 1).

\section{Sampling and analyses}

To meet the objectives set, samples from vegetables, soil and irrigation water have been collected and analyzed for metals. Vegetable samples were taken from a total of $5 \mathrm{farms}$, three from the northern part of Addis Ababa: Burayu (B); Kuskuam Upper (KU); Kuskuam Lower (KL) and two farms from Ziway area: Ziway Kentola (ZK); Ziway Ethioflora (ZE) (Figure 1). The samples represent Swiss chard (Beta vulgaris L.var. cicla), lettuce (Lectuca sativa), Ethiopia kale (Brassica carinata A. Br.), and carrot (Doucus carota). The water samples were collected using water proof plastic bottles from different water sources that the farms use for irrigation. Burayu farm utilizes water from the Gefersa River, Kuskwam farm utilizes tap water from public water supply and Ziway farms use water from Lake Ziway. Soil samples were collected from each farm for metal determination.

Leafy vegetables were handpicked and washed by distilled water and subsequently rinsed with deionized water to eliminate all contaminants including air borne pollutants. Samples from carrot were washed and sliced thinly before drying. All samples were dried in an oven at $60^{\circ} \mathrm{C}$ for $72 \mathrm{hrs}$. The dried samples were grounded and sieved through a mesh size of $1 \mathrm{~mm}$ in diameter. A 0.5 gm powdered and mixed vegetable samples were weighed and added into tubes to which $16 \mathrm{ml}$ up to $25 \mathrm{ml}$ of $69 \% \mathrm{HNO}_{3}$ were added at different intervals and digested within $4 \mathrm{hrs}$ to $6 \mathrm{hrs}$. All triplicate plant samples were digested at the same time on a block digester. The acid was evaporated until $1 \mathrm{ml}$ to $2 \mathrm{ml}$ was remaining and cooled at room temperature. After cooling, the digests were diluted by $50 \mathrm{ml}$ of distilled deionized water and kept in the refrigeration for some time until analysis. Finally, the digested vegetable samples were analyzed for heavy metals like the soil and water samples using Atomic absorption spectrophotometer (AAS), model 210 VGP. In the lab, soil samples were dried using an oven drier at $107^{\circ} \mathrm{C}$ for $24 \mathrm{hrs}$. The dried samples were grinded using a grinding disc mill and then sieved with 75 micron size and used for metal analysis. A $1.25 \mathrm{gm}$ of powdered soil sample was weighed into $50 \mathrm{ml}$ beakers 
and $5 \mathrm{ml} \mathrm{HClO}_{4}$ was added into each beaker. The samples were placed on a sand bath and heated to incipient boiling, with strong dense fumes of perchloric acid, for 45 minutes. After cooling, the digested mixture was leached by adding $45 \mathrm{ml}$ of hydrochloric acid by means of a dispenser on the water bath. Then, the mixture was filtered and diluted into $50 \mathrm{ml}$ flask and the digested samples were analyzed for heavy metals, using the AAS, model 210VGP.

The water samples were filtered with $0.45 \mu \mathrm{m}$ filters and preserved with $1 \mathrm{ml}$ of $70 \% \mathrm{HNO}_{3}$. The acidified samples were analyzed using AAS.

\section{Results and discussion}

\subsection{Metal concentration in the irrigation farms}

The analytical results presented in this section represent mean values for different number of population. The mean concentration of metals in soils of the vegetable farms is given in Table 1. Most of the metals occur at high concentration.

The highest concentrations of metals in soil samples for $\mathrm{Zn}, \mathrm{Cr}, \mathrm{Pb}$, and $\mathrm{Cd}$ are $113 \mathrm{mg} / \mathrm{kg}, 47.8 \mathrm{mg} / \mathrm{kg}, 17.7$ $\mathrm{mg} / \mathrm{kg}$ and $0.250 \mathrm{mg} / \mathrm{kg}$ respectively.

Near the vegetable farms in the northern Addis Ababa, the thickness of the soil profile reaches $12 \mathrm{~m}$ with characteristic reddish color due to hydrothermalism (Figure 2). In some part of valley bottoms northern and north western and north eastern part of Addis Ababa, the thickness is higher than the indicated value. Such soils are expected to have clay which regulates metal mobilization.

The highest mean concentration of the metals was obtained from farms found at the northern part of Addis Ababa as compared to the Ziway area. This shows that vegetable farms are operating in an area where metals are concentrated due to geogenic sources as indicated by Alemayehu (2006).

Alemayehu (2006) further indicated that the increased amounts of metals in industrially free area of northern Addis Ababa is due to hydrothermal activity where anthropogenic input is non-existent. According to the same work, metal concentration in the soils of the city is derived from geogenic source where vegetable are grown for human consumption.

\subsection{Concentration of metals in irrigation water}

Metals such as $\mathrm{Pb}$ and $\mathrm{Zn}$ are detected within the irrigation water in the farms at the northern part of Addis Ababa, which are typically derived from boreholes water that is used for irrigation (Table 2). The presence of metals in the water resources is related to high degree of water-rock interaction and long residence time. In this area the main aquifer is hydrothermally altered acidic lava flows mainly trachytes and rhyolites with associated ignmibrites, which are enriched with metals (Alemayehu, 2006). From the results one can see that irrigation water alone cannot concentrate metals into the soil and vegetables at such high concentration.

\subsection{Metals in vegetables}

All the sampled vegetable samples contain metals in different concentrations where the mean values for 10 populations are given in Table. 3. The comparative percentage plot is given in Figure 3. where the detailed metal abundance in percent is presented in Table 4.

\subsubsection{Lettuce}

The concentration of $\mathrm{Cd}, \mathrm{Cr}$ and $\mathrm{Zn}$ were the highest in lettuce at $\mathrm{KU}$ farm than the other farms and followed by B farm (both of them are from northern part of Addis Ababa). On the other hand, B farm contains higher concentration of $\mathrm{Pb}$ as compared to other farms, but $\mathrm{ZE}$ from Ziway area has the least concentration for all the metals. Lettuce has the highest mean concentration of $\mathrm{Pb}$ from $\mathrm{B}$ farm followed by lettuce from $\mathrm{KU}$, and Ethiopian kale from B farms. In more acidic environmental condition, which could be attained during rainfall, vegetables can pick up metals into their system.

The concentration of $\mathrm{Pb}$ was not significantly different in all the vegetables at different farms. Vegetables containing lead may contribute to increased $\mathrm{Pb}$ levels in blood with increased risk of anemia and neurological disorders (Gupta and Gupta, 1998).

Xue and Harrision (1991), identified a synergistic effect of $\mathrm{Zn}$ in relation to Cd uptake. They found that increasing the amount of $\mathrm{Zn}(>600 \mathrm{mg} / \mathrm{kg})$ in soils containing high levels of $\mathrm{Cd}(10 \mathrm{mg} / \mathrm{kg})$, resulted in higher concentration of Cd in lettuce leaves. Similarly, Smilde et al. (1992) found high concentrations of Cd in leafy vegetables when $\mathrm{Zn}$ concentration increases in soils. This synergistic relationship may have resulted in the elevated level of $\mathrm{Cd}$ in vegetables sampled from northern Addis Ababa where the $\mathrm{Zn}$ concentration was higher 
than the farms in Ziway. Usually at higher $\mathrm{pH}$ environment (alkaline condition), the Cd uptake is very low (John and VanLaerhoven, 1972).

The highest level (36\%) of Cd at B farm was taken by lettuce from the soil, followed by $28 \%$ and $14 \%$ in KU and ZE farms, respectively. The percentage of $\mathrm{Cr}$ in lettuce for $\mathrm{KU}$ farm (3\%) and B farm (2\%) were lower than the level at $\mathrm{ZE}$ farm (9\%). Seven percent of $\mathrm{Pb}$ was taken by lettuce in all the farms. On the other hand, the percentages for the $\mathrm{Zn}$ uptake in all the farms were relatively higher $42 \%, 41 \%$ and $30 \%$ for $\mathrm{B}$, KU and $\mathrm{ZE}$ farms, respectively.

\subsubsection{Swiss chard}

Swiss chard at $\mathrm{B}$ farm has high concentration of metals such as $\mathrm{Pb}$ and $\mathrm{Zn}$ than $\mathrm{KL}$ farm, where as they show similar value for $\mathrm{Cd}$ in both areas, but the $\mathrm{Cr}$ concentration in $\mathrm{KL}$ farm is higher than $\mathrm{B}$ farm. Transport of chromium in root is very slow (Skeffington et al., 1976), accounting for the low levels of Cr in the leafy part of the plants. The sorption of $\mathrm{Cr}$ to soils depends primarily on the clay content of the soil and, to a lesser extent, on $\mathrm{Fe}_{2} \mathrm{O}_{3}$ and the organic content of soil (Calder, 1988). Therefore, the uptake of $\mathrm{Cr}$ by vegetables grown in the northern part of Addis Ababa might be affected due to clayey nature of the soils derived from hydrothermal alteration.

Higher percentages of Cd were obtained in the Swiss chard collected from B farm (36\%) than KL farm (26\%). $\mathrm{Cr}$ and $\mathrm{Pb}$ uptake were very low, $2 \%$ and $1 \% \mathrm{Cr}$; and $1 \%$ and $2 \% \mathrm{~Pb}$ for $\mathrm{KL}$ and $\mathrm{B}$ farms respectively.

\subsubsection{Ethiopian kale}

Ethiopian kale at $\mathrm{KL}$ farm has higher concentration of $\mathrm{Zn}$ and $\mathrm{Cd}$ and followed by B farm, where as B farm has the highest concentration of $\mathrm{Cr}$ and $\mathrm{Pb}$, followed by $\mathrm{KL}$ farm for $\mathrm{Cr}$. ZK farm has slightly higher concentration of $\mathrm{Pb}$ than $\mathrm{KL}$ farm. The percentage of $\mathrm{Cd}$ in the Ethiopian kale shows highest level at KL farm (47\%), followed by $\mathrm{B}$ farm $(42 \%)$ and the small percentage at ZK farm (11\%) which were taken from the soil, but for Cr, highest percentage (19\%) for ZE farm were obtained and lower percentage (2\%), both from KU and B farms were recorded. Again, $\mathrm{Pb}$ percentages were higher at $\mathrm{ZK}$ farm (9\%), than $3 \%$ and $4 \% \mathrm{KL}$ and $\mathrm{B}$ farms, respectively. Similarly higher percentages of $\mathrm{Zn}$ were taken by Ethiopian kale similar to lettuce from the soil in KL, B and ZK farms.

\subsubsection{Carrot}

The percentage of metal uptake by carrot from soils at $\mathrm{B}$ farm was in the order of $36 \%$ for $\mathrm{Cd} ; 32 \%$ for $\mathrm{Zn} ; 2 \%$ for $\mathrm{Pb}$ and $1 \%$ for $\mathrm{Cr}$. Dowdy and Larson (1975) showed that plants intake of $\mathrm{Zn}$ is highly dependent on its concentration in soil, and a higher uptake of $\mathrm{Zn}$ is characteristic feature of leafy vegetables. Similarly, the higher concentration of metals in vegetables is related to their abundance and mobility in soils.

Generally, from the farms included in the study, both Kuskwam farms and Burayu farm have accumulated higher metals than the farms in the Ziway area, especially for lettuce and Ethiopian kale, except $\mathrm{Pb}$ from $\mathrm{ZK}$ farm that exceeds KL farm for Ethiopian kale.

In general, vegetables are among the plants that assimilate heavy metals to their metabolic need depending on their genetic make up, from the soil they are grown and the water they are irrigated with. The variations in heavy metal concentration among vegetables were attributed to the self-selectivity of the vegetable for particular metal.

In the assessment of metal concentrations in different vegetables, lettuce contains higher $\mathrm{Cr}, \mathrm{Pb}$ and $\mathrm{Zn}$ concentrations than other vegetables, whereas elevated $\mathrm{Cd}$ level was also exhibited by Ethiopian kale. Metal concentration in some vegetables also differed from one site to another depending on the abundance and soil properties of the sites. Due to the presence of thick clay in the northern Addis Ababa area the phytoavailability of the metals might be limited, although high metal concentrations in soils were detected. The high concentration of metals in the soil requires a due attention as it may bring sever problems if soil properties are altered through acidic condition.

\section{Conclusion}

In general, vegetables grown in the hydrothermally affected area of Addis Ababa tapped metals from soils. It is facilitated by the suitable soil $\mathrm{pH}$ condition that favors selective withdrawal of metals from soil by different vegetables. From the present study it is observed that there is a possibility of contamination in the soils of vegetable farms where industrial contribution is minor. Therefore, vegetables grown in areas where geogenic sources are prevalent, high metals accumulations were detected that could pose problem to consumers. In 
general, this work revealed the impact of natural environmental changes, due to geological processes, that concentrate metals into soils that instead passes metals into edible vegetables consumed by human being.

\section{References}

Alemayehu, T. (2001). The impact of uncontrolled waste disposal on surface water quality in Addis Ababa. Ethiopian Journal of Science, 24(1), 93-104.

Alemayehu, T. (2006). Heavy metal concentration in the urban Environment of Addis Ababa, Ethiopia. Journal of Soil and sediment contamination, 15 (6), 591-602.

Alloway, B. J. (1994). Toxic metals in soil-plant systems. Chichester, UK: John Wiley and Sons.

Berglund, S., Davis, R. D. L., \& Hernite, P. (1984). Utilization of sewage sludge on land: rates of application and long-term effects of metals. Dordrecht: D. Reidel Publishing, 216p.

Breward, N. (2003). Heavy metal contaminated soils associated with drained fenland in Lancashire, England, UK, revealed by BGS soil geochemistry survey. Applied Geochemistry, 18, 1663-1670. doi:10.1016/S0883-2927(03)00081-7, http://dx.doi.org/10.1016/S0883-2927(03)00081-7

Dowdy, R.H. \& Larson, W. E. (1975). The availability of sludge-borne metals to various vegetable crops, $J$. Environ. Qual, 4, 278-282. doi:10. 2134/jeq1975.00472425000400020032x, http://dx.doi.org/10.2134/jeq1975.00472425000400020032x

Freiberg, L., Nordberg, G. F. \& Vouk, B., editors. (1997). Handbook on the toxicology of metals. Amsterdam, New York, Oxford: Elsevier /North Holland Biomedical Press.

Getaneh, W. \& Alemayehu, T. (2006). Metal contamination of the environment by placer and primary gold mining in the Adola region, Southern Ethiopia. Environmental Geology Journal, 50, 339-352 doi:10.1007/s00254-006-0213-5, http://dx.doi.org/10.1007/s00254-006-0213-5

Gupta, U. C. \& Gupta, S. C. (1998). 'Trace element toxicity relationships to crop production and livestock and human health: Implication for management', Commun. Soil. Sci. Plant Anal, 29, 1491-1522. doi:10.1080/00103629809370045, http://dx.doi.org/10.1080/00103629809370045

Hem, J. D. (1992). Study and interpretation of chemical characteristics of natural water. US Geological Survey Professional Paper, 1473, 363p.

Itanna, F. \& Olsson, M. (2004). Land Degradation in Addis in Ababa due to Industrial and Urban Development. Ethiopian Journal of Developmental Research, 26(1), 77-100.

Itanna, F. (2002). Metals in leafy vegetables grown in Addis Ababa and toxicological implications. Ethiopian Journal of Health Development, 16(3), 295-302.

John, M. K. \& VanLaerhoven, C. J. (1972). Lead distribution in plants grown on a contaminated soil. Environ Letters, 3(2), 111-116. doi:10.1080/00139307209435459, http://dx.doi.org/10.1080/00139307209435459

Jung, M. C. (2001). Heavy metal contamination of soils and waters in and around Imcheon Au-Ag mine, Korea. Applied geochemistry, 16, 1369-1375. doi:10.1016/S0883-2927(01)00040-3, http://dx.doi.org/10.1016/S0883-2927(01)00040-3

Khan, D. H., \& Frankland, B. (1983). Effects of cadmium and lead on radish plants with particular reference to movement of metals through soil profile and plant. Plant and Soil, 70, 335-345. doi:10.1007/BF02374890, http://dx.doi.org/10.1007/BF02374890

Klein, D. H. (1972). Mercury and other metals in urban soils. Environmental Science \& Technology, 6, 550-559. doi:10.1021/es60065a003, http://dx.doi.org/10.1021/es60065a003

Lacatusu, R., Rauta, C., Carstea, S. \& Ghelase, I. (1996). Soil-plant-man relationships in heavy metal polluted areas in Romania. Applied Geochemistry, 11, 105-107. doi:10.1016/0883-2927(95)00101-8, http://dx.doi.org/10.1016/0883-2927(95)00101-8

Landberg, T. \& Greger, M. (1996). Differences in uptake and tolerance to heavy metals in Salix from unpolluted and polluted areas. Applied Geochemistry, 11, 175-180. doi:10.1016/0883-2927(95)00082-8, http://dx.doi.org/10.1016/0883-2927(95)00082-8

Lee, C. G, Chon, H. T. \& Jung, M. C. (2001). Heavy metal contamination in the vicinity of the Daduk Au-Ag-Pb-Zn mine in Korea. Applied Geochemistry, 16, 1377-1386. doi:10.1016/S0883-2927(01)00038-5, http://dx.doi.org/10.1016/S0883-2927(01)00038-5 
Li, X., Poon, C. \& Liu, P. S. (2001). Heavy metal contamination of urban soils and street dusts in Hong Kong. Applied Geochemistry, 16, 1361-1368. doi:10.1016/S0883-2927(01)00045-2, http://dx.doi.org/10.1016/S0883-2927(01)00045-2

Madrid, F., Liphadzi, M. S. \& Kirkham, M. B. (2003). Heavy metal displacement in Chelate irrigated soil during phytoremediation. Jour Hydrology, 272, 107-119. doi:10.1016/S0022-1694(02)00258-5, http://dx.doi.org/10.1016/S0022-1694(02)00258-5

Pendias, A. K. \& Pendias, H. (1992). Trace elements in soil and plants. 2nd edn. CRC Press: Boca Raton, 271-76.

Rieuwerts, J. and Farago, M. (1996). Heavy metal pollution in the cicinity of a secondary lead smelter in the Czech Republic. Applied Geochemistry, 11, 17-23. doi:10.1016/0883-2927(95)00050-X, http://dx.doi.org/10.1016/0883-2927(95)00050-X

Salomons, W. \& Forstner, U., editors. (1988). Chemistry and biology of solid waste. Dredge Materials and mine tailing. Berlin: Springer Verlag.

Sidenko, N. V. \& Sheriff, B. L. (2005). The attenuation of Ni, Zn and Cu by secondary Fe phases of different crystallinity from surface and ground waters of two sulphide mine tailings in Manitoba, Canada. Applied
Geochemistry,
20 ,
1180-1194.
doi:10.1016/j.apgeochem.2005.01.012,

http://dx.doi.org/10.1016/j.apgeochem.2005.01.012

Smilde, B., Van Luit, K.W. \& Van Driel, W. (1992). The extraction by soil and absorption by plants of applied zinc and cadmium. Plant and Soil, 143, 233-238. doi:10.1007/BF00007878, http://dx.doi.org/10.1007/BF00007878

Ustayak, S. \& Petrikova, V. (1996). Heavy metal pollution in soils and crops in northen Bohemia. Applied Geochemistry, 11, 77-80. doi:10.1016/0883-2927(95)00065-8, http://dx.doi.org/10.1016/0883-2927(95)00065-8

Verner, J. F. \& Ramsey, M. H. (1996). Heavy metals contamination of soils around a $\mathrm{Pb}-\mathrm{Zn}$ smelter in Bukowno, Poland. Applied Geochemistry, 11, 11-16. doi:10.1016/0883-2927(95)00093-3, http://dx.doi.org/10.1016/0883-2927(95)00093-3

WHO. (1984). Guideline for Drinking Water Quality. Health Criteria and Supporting Information, 2, 63-315.

Xue, Q. \& Harrison, H. C. (1991). 'Effect of soil zinc, pH and cultivar uptake in leaf lettuce (Lactucasativa L. var. crispa)', Commun. Soil Sci. Plant Anal, 22, 975-991. doi:10.1080/00103629109368467, http://dx.doi.org/10.1080/00103629109368467

Table 1. Mean values of metals in soils of the vegetable farms

\begin{tabular}{|c|c|c|c|c|c|}
\hline Metals (mg.kg-1) & ZK & ZE & B & KU & KL \\
\hline $\mathrm{Cd}$ & $0.180 \pm 0.070$ & $0.220 \pm 0.040$ & $0.140 \pm 0.080$ & $0.250 \pm 0.080$ & $0.190 \pm 0.050$ \\
\hline $\mathrm{Cr}$ & $3.0 \pm 0.06$ & $8.44 \pm 1.29$ & $47.78 \pm 8.91$ & $31.24 \pm 1.49$ & $32.6 \pm 5.09$ \\
\hline $\mathrm{Pb}$ & $6.02 \pm 0.34$ & $7.12 \pm 2.75$ & $17.66 \pm 1.66$ & $16.38 \pm 3.01$ & $11.17 \pm 1.46$ \\
\hline $\mathrm{Zn}$ & $49.98 \pm 0.27$ & $68.42 \pm 4.78$ & $88.47 \pm 13.04$ & $112.7 \pm 8.34$ & $78.02 \pm 8.27$ \\
\hline
\end{tabular}

Table 2. Mean values of metals in irrigated water of the vegetable farms. n.d. $=$ not detected

\begin{tabular}{|c|c|c|c|c|c|}
\hline Metals $(\mu \mathrm{g} / \mathrm{l})$ & ZK & ZE & B & KU & KL \\
\hline $\mathrm{Cd}$ & n.d. & n.d. & n.d. & n.d. & n.d. \\
\hline $\mathrm{Cr}$ & n.d. & n.d. & n.d. & n.d. & n.d. \\
\hline $\mathrm{Pb}$ & n.d. & n.d. & n.d. & $24 \pm 11.09$ & $10.6 \pm 8.40$ \\
\hline $\mathrm{Zn}$ & n.d. & n.d. & n.d. & $32.78 \pm 0.45$ & $30.37 \pm 0.29$ \\
\hline
\end{tabular}


Table 3. Mean values of metals in vegetable samples

\begin{tabular}{|c|c|c|c|c|c|c|c|c|c|}
\hline \multirow{2}{*}{$\begin{array}{l}\text { Metal } \\
(\mathrm{mg} / \mathrm{kg})\end{array}$} & \multicolumn{3}{|c|}{ Lettuce } & \multicolumn{2}{|c|}{ Swiss Chard } & \multicolumn{3}{|c|}{ Ethiopian Kale } & \multirow{2}{*}{$\begin{array}{l}\text { Carrot } \\
\text { B }\end{array}$} \\
\hline & $\mathrm{KU}$ & $\mathrm{B}$ & ZE & KL & B & KL & B & $\mathrm{ZK}$ & \\
\hline $\mathrm{Cd}$ & $0.070 \pm .0 .06$ & $0.050 \pm 0.060$ & $0.030 \pm 0.040$ & $0.050 \pm 0.040$ & $0.050 \pm 0.050$ & $\begin{array}{l}0.090 \\
\pm 0.100\end{array}$ & $\begin{array}{l}0.060 \pm \\
0.020\end{array}$ & $\begin{array}{l}0.020 \pm \\
0.020\end{array}$ & $\begin{array}{l}0.050 \pm \\
0.03\end{array}$ \\
\hline $\mathrm{Cr}$ & $1.08 \pm 0.52$ & $0.81 \pm 0.19$ & $0.76 \pm 0.27$ & $0.68 \pm 0.58$ & $0.57 \pm 0.31$ & $\begin{array}{l}0.62 \\
\pm 0.29\end{array}$ & $\begin{array}{l}0.76 \pm \\
0.42\end{array}$ & $\begin{array}{l}0.57 \pm \\
0.30\end{array}$ & $\begin{array}{l}0.52 \pm \\
0.71\end{array}$ \\
\hline $\mathrm{Pb}$ & $1.17 \pm 0.46$ & $1.24 \pm 0.28$ & $0.52 \pm 0.39$ & $0.16 \pm 0.06$ & $0.43 \pm 0.54$ & $\begin{array}{l}0.36 \\
\pm 0.23\end{array}$ & $\begin{array}{l}0.73 \pm \\
0.24\end{array}$ & $\begin{array}{l}0.53 \pm \\
0.45\end{array}$ & $\begin{array}{l}0.40 \pm \\
0.32\end{array}$ \\
\hline $\mathrm{Zn}$ & $46.29 \pm 0.61$ & $36.83 \pm 1.32$ & $20.76 \pm 0.39$ & $30.35 \pm 0.87$ & $31.68 \pm 0.89$ & $\begin{array}{l}34.02 \\
\pm 1.18\end{array}$ & $\begin{array}{l}33.10 \pm \\
4.41\end{array}$ & $\begin{array}{l}17.69 \pm \\
1.20\end{array}$ & $\begin{array}{l}28.34 \pm \\
0.12\end{array}$ \\
\hline
\end{tabular}

Table 4. Percentage of metal accumulations in vegetables tissue from the Soil

\begin{tabular}{|c|c|c|c|c|c|c|}
\hline \multirow{2}{*}{ Vegetables } & \multirow{2}{*}{ Metals } & \multicolumn{5}{|c|}{ Vegetable farms } \\
\hline & & KU & KL & B & $\mathrm{ZE}$ & $\mathrm{ZK}$ \\
\hline \multirow{4}{*}{ Lettuce } & $\mathrm{Cd}$ & $28 \%$ & - & $36 \%$ & $14 \%$ & - \\
\hline & $\mathrm{Cr}$ & $3 \%$ & - & $2 \%$ & $9 \%$ & - \\
\hline & $\mathrm{Pb}$ & $7 \%$ & - & $7 \%$ & $7 \%$ & - \\
\hline & $\mathrm{Zn}$ & $41 \%$ & - & $42 \%$ & $30 \%$ & - \\
\hline \multirow{4}{*}{ Ethiopian Kale } & $\mathrm{Cd}$ & - & $47 \%$ & $42 \%$ & - & $11 \%$ \\
\hline & $\mathrm{Cr}$ & - & $2 \%$ & $2 \%$ & - & $19 \%$ \\
\hline & $\mathrm{Pb}$ & - & $3 \%$ & $4 \%$ & - & $9 \%$ \\
\hline & $\mathrm{Zn}$ & - & $44 \%$ & $37 \%$ & - & $35 \%$ \\
\hline \multirow{4}{*}{ Swiss chard } & $\mathrm{Cd}$ & - & $26 \%$ & $36 \%$ & - & - \\
\hline & $\mathrm{Cr}$ & - & $2 \%$ & $1 \%$ & - & - \\
\hline & $\mathrm{Pb}$ & - & $1 \%$ & $2 \%$ & - & - \\
\hline & $\mathrm{Zn}$ & - & $39 \%$ & $36 \%$ & - & - \\
\hline \multirow{4}{*}{ Carrot } & $\mathrm{Cd}$ & - & - & $36 \%$ & - & - \\
\hline & $\mathrm{Cr}$ & - & - & $1 \%$ & - & - \\
\hline & $\mathrm{Pb}$ & - & - & $2 \%$ & - & - \\
\hline & $\mathrm{Zn}$ & - & - & $32 \%$ & - & - \\
\hline
\end{tabular}




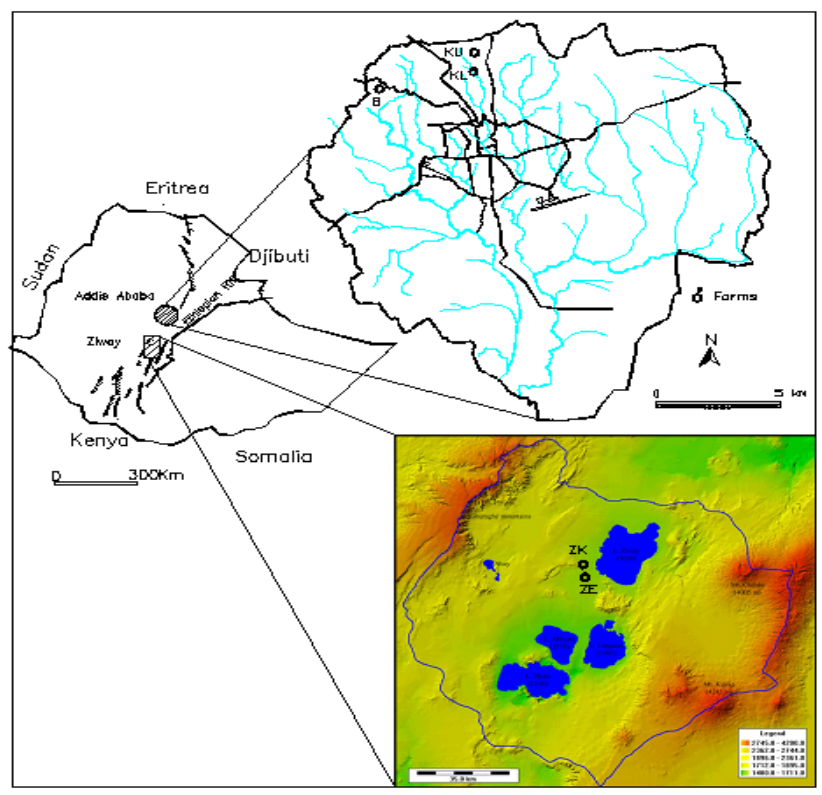

Figure 1. Location map of the Farms, B: Burayu farm, KU: Kuskuam Upper farm, KL: Kuskuam Lower farm, ZK: Ziway Kentola farm and ZE: Ziway Ethioflora farm

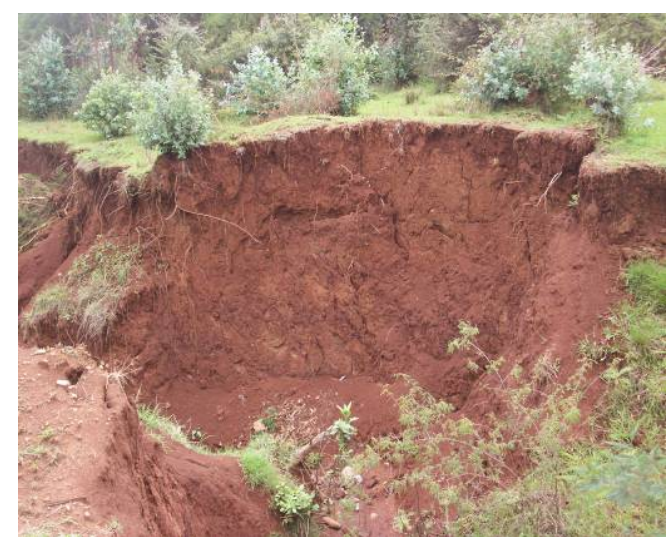

Figure 2. Typical soil of Burayu and Kuskwam area

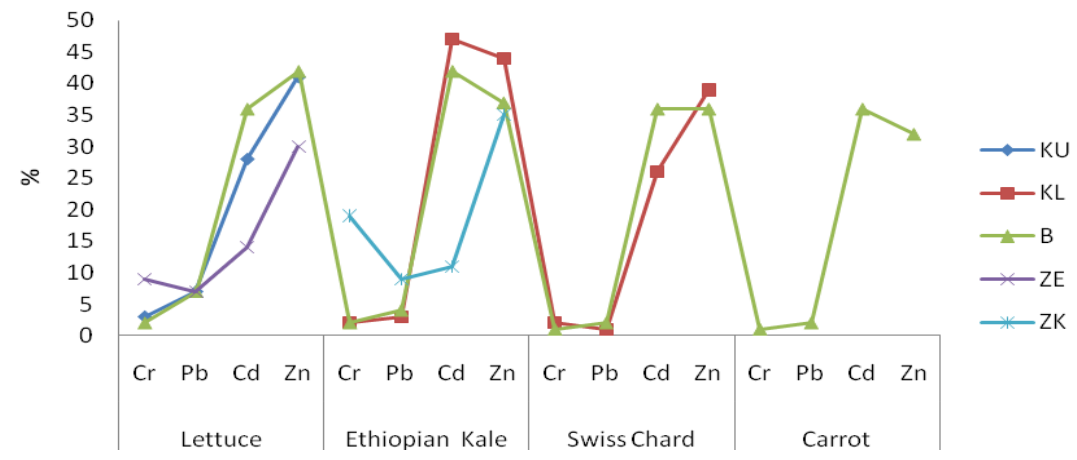

Figure 3. Comparative plot that shows metal concentration in different farms within different vegetables 